\title{
UMA DIGRESSÃO
}

\section{Maria do Bom Remédio de Souza Sanches ${ }^{1}$}

Resumo: O presente texto trata do memorial sobre a trajetória escolar de Maria do Bom Remédio de Souza Sanches, ex-integrante do Programa Conexões de Saberes. Tem como objetivo apresentar os passos percorridos desde o início da educação básica até a entrada à UFPA e quais os principais entraves de estudantes das comunidades populares adentrarem o ensino superior público. A memória foi usada como principal referência para construção do material. Em seus resultados, apresenta os esforços individual e coletivo para que de fato a educação seja uma questão de direito e não de privilégio de poucos.

Ao começar a escrever, minhas lembranças fluem como se fossem um filme passando, no qual assisto a maioria das cenas. Gostaria de ter feito diferente, mas me dou conta que não estou mais lá, não posso mais mudar o que passou. Não é nada fácil falar do passado, porque não lembramos somente das coisas boas; lembramos também das coisas tristes, das mágoas.

Pensei em começar esse relato falando das minhas primeiras lembranças escolares, mas mudei de idéia; gostaria de citar um verso de um poema de Antônio Miranda, que diz haja palavras para averbar memórias, pois ele representa o meu estado nesse momento em que relato minhas memórias. Uma emoção muito grande se apossa de mim e para que essas lembranças se eternizem, busco palavras para expressá-las.

Reporto-me ao título para dizer-lhes que de tempo em tempo sempre lembro o meu passado, só para não perder de vista o que estou buscando; para mim, que carrego desde a infância e vivo sonhando que o caminho de se alcançar uma vida mais digna é através da educação, do conhecimento, preciso desta sombra não atrás de mim como um passado que deve ser esquecido; mas na minha mente, como memória, uma lição para que eu possa trilhar meu futuro.

Por maior que seja o obstáculo, procuro vencê-lo, como venci as dificuldades para buscar os estudos morando no interior. A falta de recursos, a escola que sempre estava distante do aluno, tanto no que se refere ao trajeto casa/escola quanto ao modelo de ensinoaprendizagem, todos esses obstáculos, só quem morou e mora no interior, na zona rural, sabe e já sentiu na pele.

Sei que é impossível registrar minhas experiências sem falar de muitas pessoas; pessoas que estiveram ao meu lado me dando forças, algumas até foram duras demais (só hoje

\footnotetext{
${ }^{1}$ Acadêmica* de Licenciatura Plena em Letras da UFPA, Campus Universitário do Tocantins/Cametá, e-mail: remediobom@yahoo.com.br

* atualizado pela última vez em 2008.
}

Revista PET Interdisciplinar e Programa Conexões /UFPA On-line. Ed. Especial - 2017, BELÉM/ PA - ISSN 2447-097X 
percebi que me impulsionaram a seguir em frente quando eu estava prestes a desistir). Mas precisava de qualquer maneira vencer os desafios que estavam me conduzindo a desistir da minha busca.

Quando falo da minha busca por uma vida mais digna, por aquilo que eu não tinha, não estou me referindo só aos bens materiais. Falo de cidadania, de respeito. Tenho os melhores pais do mundo, um lar afetuoso, mas eu queria ir para longe, onde, meus olhos não conseguiam enxergar com clareza, o que para mim hoje não é tão bonito quanto o meu lar, quanto a infância que eu vivia.

Por isso, nestas memórias pretendo revisar partes das cenas de alguns momentos da minha vida pessoal e educacional, e para os que lerem, que possam de ter um exemplo de vida com a minha trajetória, também semelhante a outras situações que acontecem com outros sujeitos, mas que precisam ser mudadas.

Pretendo continuar minha caminhada porque acredito na revolução educacional. Essa revolução tem que partir de dentro de cada um de nós para depois alcançar o meio, a sociedade em que vivemos.

Isso sei, porque fui eu quem sentiu cada conseqüência de erros, a represália; também sei o quanto é grande a felicidade quando se alcança uma vitória. Por isso, posso dizer que sou feliz, porque luto pelos meus objetivos, pelo que acredito, mesmo que tudo seja sonho como muitas pessoas dizem. Confesso: sou uma grande sonhadora!

"Haja fé, discernimento

Haja paz."

Antonio Miranda (2006).

\section{O início de uma grande caminhada}

Considero complicado falar das imagens de minhas lembranças, pois me fazem lembrar coisas que aconteciam e eu não sabia bem explicar; expectativas, sonhos, desejos e também frustrações. Fecho os olhos e aquela imagem surge na minha memória; era eu, não a mesma de hoje, mas aquela menina franzina de sete anos que ia para o seu primeiro dia de aula; imaginava como ia ser a aula, a professora, os colegas.

Foi difícil, a distância era muito grande entre a casa e a escola, mais ou menos três quilômetros. Tinha que atravessar dois igarapés, sendo que um, no inverno, só se conseguia 
chegar do outro lado se fosse de canoa, a ponte era de árvores e, na época da cheia, ela desaparecia sob as águas.

Como se isso não fosse o bastante para meu coração suportar, na escola a professora tinha alunos de várias séries e idades diferentes; e ela só falou comigo quando eu cheguei. Pediu meu caderno e me devolveu após copiar no quadro para os outros o conteúdo, no final, pediu o caderno para corrigir.

Mas não me importava, eu queria era aprender a ler e escrever para saber o que estava escrito nos livros que ganhara da minha tia. Essa imagem marcou muito a minha vida, apesar de só ter ido uma semana na aula. Não aprendi nem o nome da escola, parei. Meus pais não conseguiam ir me deixar e buscar todos os dias, pois precisavam trabalhar na roça cedo.

Nessa época, éramos cinco irmãos; eu, a mais velha, com sete anos já ajudava. Como de costume no interior, o irmão mais velho cuida dos mais novos para os pais irem trabalhar na roça. Morávamos em um casebre simples, próximo a um igarapé. Havia florestas por todos os lados, era um ambiente tranqüilo e lá meus pais plantavam mandioca, milho, arroz, dentre outros produtos. Todos para o nosso sustento.

Não sei o que dizer. Faltam as lembranças, mas...Tudo aconteceu em 1989. Morei com uma prima da minha mãe. Essa prima era professora. Assim eu poderia estudar. Mas a saudade era muito grande, lembrava dos meus pais e dos meus irmãos, das brincadeiras; e resolvi dizer que queria voltar para minha casa. E, desse modo, não terminei o ano letivo.

Então meu pai resolveu mudar para a vila (Bom Jardim), para que eu e minha irmã pudéssemos estudar. Mas alegria não durou; tivemos que voltar para o sítio por que lá estava o trabalho dele e o nosso sustento. Continuei os estudos em uma escola mais próxima, que funcionava na casa da professora, em uma saleta onde ficávamos sentados à mesa, apertados. Às vezes, o chão se tornava mais confortável do que ficar na mesa.

Sei que sou muito teimosa. Estudei por insistência, porque a vida não foi fácil. Eu era criança, mas já tinha muitas responsabilidades: quando eu não cuidava dos meus irmãos, estava na roça capinando, ajudando na fabricação da farinha e apanhando pimenta. Contudo, considero que fui feliz, vivenciei coisas que foram importantes na formação do meu caráter, aprendi a valorizar a família. Mesmo com o baixo nível de escolaridade de meus pais, eles foram meus grandes mestres. Por isso, selecionei essa imagem das muitas que tenho, porque essa lembrança não é só minha, é de muitas crianças que viveram, e vivem, na mesma situação em que eu vivia. Morar na zona rural não é fácil para quem quer estudar, pois a maioria das escolas fica distante e por isso a maior parte das crianças desiste dos estudos.

Revista PET Interdisciplinar e Programa Conexões /UFPA On-line. Ed. Especial - 2017, BELÉM/ PA - ISSN 2447-097X 
Para, Eduardo de Lima (2006), a evasão escolar é um problema sério e complexo na educação, assim como as formas de avaliação, reprovação escolar e currículo. Por outro lado, a Constituição Federal, que garante o ensino gratuito e de qualidade às crianças e adolescente, a meu ver não se faz presente na vida de todos, pois o que se observa é que a maioria das crianças não completa o ensino fundamental por vários motivos, dentre eles os citados acima. Acrescenta-se ainda que o Estatuto da Criança e do Adolescente (ECA), parágrafos $1^{\circ}$ e $5^{\circ}$, garantem igualdade de condições e permanência na escola, assim como acesso à escola pública de qualidade próxima de sua residência, direitos que hoje conheço, mas não se fizeram presentes nos primeiros anos da minha trajetória educacional

Para combater a evasão escolar, é preciso discutir sobre os outros pontos que citei acima, relacionando-os, assim como realizar projetos de complementação da renda familiar, já que muitas crianças abandonam os estudos para ajudar os pais no trabalho para suprir às necessidades da família. Com isso acredito que seja possível resgatar o aluno evadido.

E assim foi. Estudei até a terceira série nas turmas multisseriadas. Confesso que considero essa modalidade de ensino uma mutilação tanto para o professor quanto para o aluno: sem aproveitamento porque o professor não pode, sobre hipótese alguma, ter sucesso ministrando aulas para alunos de diferentes séries. Acredito que para resolver esse problema é preciso que haja professores suficientes para suprir as carências, não me refiro apenas à quantidade de alunos mas, que sejam qualificados.

Os anos passaram. Aos11 anos, conheci uma turma diferente na escola, quando estudei a $4^{\mathrm{a}}$. série. Os alunos ficavam admirados da minha coragem de ir sozinha para a escola a pé todos os dias. Nessa turma, todos estavam na mesma série, pouca diferença de idade, era um horizonte novo para mim, pois ficava sonhando no ano seguinte já na $5^{\mathrm{a}}$. série. Onde eu iria estudar? A maioria dos estudantes parava por aí, continuavam aqueles que iam para a cidade morar em casa de família ou na Vila de Carapajó, a mais próxima de Bom Jardim. Os que estudavam lá saíam de madrugada para poder chegar às sete da manhã, horário de entrada, opção esta que estava fora de cogitação. Era preciso sair de casa e ir morar na casa de alguma família na cidade. Mas como eu iria convencer meus pais?

\section{Quem sabe faz à hora, não espera acontecer.}

Fui aprovada para a $5^{\mathrm{a}}$. série; após pedidos, choros e promessas de que me comportaria e não os decepcionaria, veio a felicidade: meus pais permitiram que eu fosse estudar na cidade 
(Cametá). Ao mesmo tempo, me dava uma vontade de chorar. Mas eu não podia desistir, pensando que não me acostumaria como da outra vez: me fiz de forte e dura como uma rocha.

Foi por isso que coloquei esse título neste memorial, para mostrar mais uma cena do filme da minha vida, que considero muito importante, dado poder estar aqui. Foi um passo muito importante nessa jornada, considerando a idade que eu tinha (11 anos). Não foi fácil sair do seio de minha família e ir morar longe; para isso acontecer, tive que prometer que, mesmo longe de meus pais, tinha que me manter obediente.

Era uma menina passando para a adolescência. Tive que pular essa fase, pois qualquer deslize eu teria que esquecer a escola e voltar para o interior. Foi esse o acordo para eu poder vir.

Minha vida foi muito difícil, tanto na casa onde eu morava como na escola. Sofri o preconceito com a linguagem que eu trouxe do interior: várias vezes eu era consertada nas minhas falas. As meninas da escola eram vaidosas, ao contrário de mim, por isso pouco conversavam comigo, a não ser quando se tratava de um assunto que eu sabia e isso girava em torno dos conteúdos da sala de aula. Nos anos seguintes do Ensino Fundamental, as coisas foram mudando para mim. Já estava entrosada com os colegas; conversava assuntos que não conversei com a minha mãe, como namoro, sexo, drogas. Enfim, eles já não me chamavam mais $D u$ sitio - expressão preconceituosa usada para se referir às pessoas que moram no interior.

Mas estudar também traz dificuldades. Durante o ensino fundamental, sempre que ficava em recuperação era em matemática. Isso aconteceu na $6^{\mathrm{a}}$. e na $8^{\mathrm{a}}$. série. Essa é a realidade de muitos alunos. Na minha situação, acontecia devido à dificuldade de não conseguir acompanhar o raciocínio do professor. Outro motivo era devido morar em casa de família: não tinha tempo para estudar; era nas madrugadas que buscava superar as lacunas deixadas pelas aulas, refazia exercícios e lia.

A casa em que eu morava era da prima de minha mãe. Eu ajudava nos trabalhos domésticos e nas suas vendas de produtos de beleza. Ia à casa de suas clientes fazer a entrega dos produtos e receber os pagamentos, em troca de casa e comida. Todas essas tarefas levavam o meu tempo, um tempo não podia recuperar.

Esse foi um dos motivos que me levaram a escolher esse título que foi extraído de uma composição de Geraldo Vandré da época de chumbo, que retrata uma época de censura contra os pensamentos e idéias que iam de encontro ao sistema político da época. Esse fato me faz voltar ao passado e observar, com o conhecimento de hoje, o quanto fui reprimida, e sempre 
somos quando temos que deixar de fazer nossas tarefas e fazer as de outro, sem no mínimo receber um agradecimento.

Outro motivo que não posso deixar de relatar é quando temos que optar por um padrão mais aceito que o nosso (a classe popular), como o modo de vestir e falar, por outro considerado certo. Por traz desse discurso, que diz o que é certo e o que é errado, existe uma ideologia, a dos dominantes. Esses que possuem o poder aquisitivo maior estabelecem parâmetros sociais a ser seguidos, para poder ser aceito no meio social, por exemplo: o domínio da norma culta. Observo que as pessoas que não utilizam a norma culta são estigmatizadas e a escola não se preocupa em resolver o problema. Geralmente ela tenta castrar os conhecimentos de mundo trazidos pelo aluno, dizendo a ele a forma certa de falar Assim, deixa de explicar para o aluno que em determinados momentos ele pode usar a norma culta e em outro a coloquial.

No dizer de Soares (1997), a escola ainda é contra o povo, o que comprova os altos índices de repetência e evasão. Ressalta ainda que a escola não está preparada para educar as pessoas das camadas populares.

Mas não foi somente por isso que coloquei esse título, e sim porque ele me lembra perseverança, a que tive para buscar os meus ideais. Acredito que somos capazes de conseguir muitas vitórias se fizermos por nós aquilo que acreditamos, abraçando nosso sonho, lutando contra os obstáculos que, sem dúvida, irão surgir, porque as coisas não caem do céu, somos nós que buscamos.

"E de esperança

Mais teimoso que uma criança".

(Milton nascimento e Fernando Brant)

\section{A caminhada continua}

Outra cena desse filme que flui na minha memória, sem que eu faça esforços, aconteceu em 1998, quando eu estava aprovada para cursar o segundo grau (nível médio). Foi uma grande vitória na vida, principalmente para quem chegou ainda menina do interior. Eu estava muito feliz; me inscrevi na escola Osvaldina Muniz, para fazer o teste de seleção, afim de cursar o magistério, porque queria ser professora.

Durante os três anos do meu curso, tive excelentes professores que ajudaram muito na minha formação; fiz muitos amigos e sonhávamos juntos com um curso superior. Nesse 
período, já não morava na casa de minha tia. Morava com outra família, foi então que conheci aquele que hoje é meu marido.

Veio o amor e, passado um ano, fomos morar juntos. Consegui concluir o segundo grau, mas por falta de recursos financeiros não me inscrevi no vestibular. Em 2002, consegui me inscrever, mas não fui aprovada.

Já em 2003, com o nascimento do meu filho, não pude fazer a prova, porque não tinha quem cuidasse dele para eu ir estudar. Em 2004 consegui a isenção, mas, pelo motivo do meu filho estar doente, não realizei a segunda fase: fui eliminada automaticamente. Somente em 2006 pude sentir a alegria de ser aprovada no vestibular e também de ser mãe pela segunda vez (agora era uma menina).

Como vocês puderam ler, não foi nada fácil a minha entrada na universidade. Mas nada comparado com a dificuldade que enfrentei no início para ir às aulas. Eu tinha um bebê pequeno com cinco dias de nascido, tive que deixar com a minha irmã de quinze anos para poder estudar. Com meus pais morando em outro lugar, não tendo muito com quem contar e nos momentos de angústia só me lembrava de um ser em quem eu acredito muito. Penso que eu não estou sozinha, pois Ele está comigo. Mesmo nos momentos mais difíceis Ele segura a minha mão e não me deixa cair. Esse ser de quem falo é Deus.

\section{Referências bibliográficas}

BRASIL. Lei Nº 8069/1990 Estatuto da Criança e do Adolescente. Brasília - DF, 1990.

MIRANDA, Antonio. Ilustrada memórias do ser. Disponível em: <www.antoniomiranda.com.br-poesia> Acesso em: 27 de junho de 2008.

NASCIMENTO, Milton e BRANDT, Fernando. O vendedor de sonhos. In: Yauarete. Columbia, 1987. Faixa 02.

REIS, Márcia Helena pinheiro, CARDOSO,Neves . A evasão escolar como fenômeno de exclusão social: Um estudo no centro integrado de formação de Cametá. TCC Pedagogia 97. Cametá-Pa, 2001.

SOARES, Magda. Linguagem e escola: Uma perspectiva social. São Paulo - SP: Editora Ática, 1997.

Revista PET Interdisciplinar e Programa Conexões /UFPA On-line. Ed. Especial - 2017, BELÉM/ PA - ISSN 2447-097X 